\title{
PETERNAK AYAM KAMPONG DI DESA PANGGUNGJATI KECAMATAN TAKTAKAN KOTA SERANG PROPINSI BANTEN
}

\author{
Fara Fitriyani ${ }^{1}$, Ika Utami Widyaningsih ${ }^{2}$ \\ 'Jurusan Akuntansi, Universitas Sultan Ageng Tirtayasa \\ ${ }^{2}$ Jurusan Manajemen, Universitas Sultan Ageng Tirtayasa \\ Email: ․ㅏara 0606@untirta.ac.id, 2ika utami@ymail.com
}

\begin{abstract}
Abstrak
Desa Panggungjati Kecamatan Taktakan Kota Serang Propinsi Banten merupakan salah satu daerah peternak ayam kampong. Peternak mengalami kendala dalam proses produksi yang berkelanjutan karena bibit ayam yang dimiliki peternak jumlahnya terbatas dan sulitnya mendapatkan bibit diluar daerah. Selain itu, peternak juga memiliki kendala dalam memasarkan ayam kampong yang telah terdiversifikasi karena karakteristik konsumen yang beragam.

Pengabdian masyarakat dilakukan untuk memberikan metode mencari informasi mendapatkan bibit dengan mudah, cepat dan berkualitas serta meningkatkan pemasaran ayam kampong dengan memanfaatkan teknologi informasi dengan internet. Hasil yang ingin dicapai adalah peternak dapat melakukan proses produksi yang berkelanjutan dan memiliki manajemen pemasaran yang baik sehingga dapat meningkatkan pendapatan.

Metode pelaksanaan yang dilakukan adalah dengan melakukan identifikasi pengetahuan peternak, melakukan FGD pada masing-masing peternak, melakukan pelatihan belajar internet, penerapan internet masuk desa, evaluasi dan monitoring.
\end{abstract}

Key words: Peternak, teknologi informasi, internet, pendapatan

\section{PENDAHULUAN}

\section{Analisis Situasi}

Pemenuhan kebutuhan protein hewani dari produk unggas harus diimbangi dengan peningkatan populasi ternak unggas, sehingga produk ternak unggas mampu memenuhi kebutuhan protein hewani masyarakat. Pembangunan peternakan terus dilanjutkan melalui peningkatan usaha diversifikasi, intensifikasi ternak, didukung oleh usaha pengembangan dan pemanfaatan ilmu pengetahuan serta teknologi. Ayam Kampong merupakan plasma nutfah Indonesia yang sangat potensial untuk dikembangkan, karena secara geografis sangat mendukung dengan penyebaran populasi hampir di seluruh pedesaan di Indonesia.

Peluang usaha ternak ayam Kampong sangat luas ditinjau dari agroekosistem dan lingkungan hidup, seiring dengan meningkatnya pendapatan dan kesadaran masyarakat terhadap pentingnya kuantitas dan kualitas bahan pangan yang bergizi dan aman dikonsumsi. Keadaan tersebut berpengaruh pada peningkatan konsumsi produk ternak berupa daging, telur dan susu yang aman, sehat, unggul dan halal (ASUH), mendukung pemenuhan gizi dan kesehatan masyarakat menuju sumber daya manusia yang lebih berkualitas. Ketersediaan dan terpenuhinya berbagai produk ternak merupakan kontribusi nyata subsektor peternakan dalam pembangunan pertanian nasional.

Peternak Indonesia perlu tanggap terhadap laju perkembangan teknologi. Pemanfaatan perkembangan teknologi tersebut dilakukan untuk mendukung sistem usaha peternakan. Selain untuk mencari informasi tentang bagaimana meningkatkan produktivitas dan reproduktivitas ayam kampong, teknologi juga dapat dijadikan sebagai sarana berkomunikasi dengan peternak lain ataupun stakeholder yang berada jauh untuk melakukan fungsi pemasaran.

Menurut data terakhir tahun 2017 (Kominfo, 2017) tidak kurang dari 112 juta penduduk Indonesia telah mengakses internet. Internet telah menjangkau sebagian besar daerah perkotaan dan pedesaan. Jaringan internet berkembang seiring dengan perkembangan telepon selular. Daerah yang telah terjangkau oleh komunikasi 
telepon selular maka daerah tersebut juga dapat mengakses internet. Jumlah pengguna Internet kian besar dan semakin berkembang, hingga seakan telah mewujudkan budaya disetiap kehidupan.

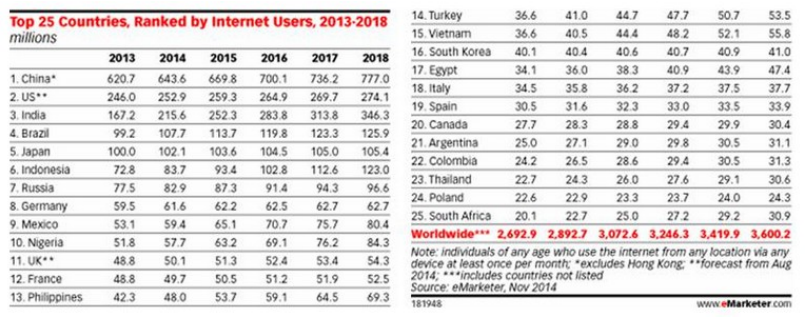

Gambar 1

Data penggunaan Internet

Internet juga mempunyai pengaruh yang besar atas ilmu, dan pandangan dunia. Pengguna di seluruh dunia mempunyai akses Internet yang mudah atas bermacam-macam informasi. Perkembangan Internet juga telah mempengaruhi perkembangan ekonomi. Berbagai transaksi jual beli yang sebelumnya hanya bisa dilakukan dengan cara tatap muka (dan sebagian sangat kecil melalui pos atau telepon), kini sangat mudah dan sering dilakukan melalui Internet. Transaksi melalui Internet ini dikenal dengan nama e-commerce. Kegiatan peternakan bukan hanya sebatas produksi untuk memperoleh hasil yang banyak, tetapi bagaimana pemasaran hasil peternakan tersebut agar dapat menguntungkan dari segi ekonomi. Produktivitas peternakan yang tinggi akan menjadi sia-sia bila tidak sepenuhnya diserap oleh pasar. Oleh karena itu pemasaran hasil peternakan menjadi kata kunci dalam kegiatan peternakan.

Desa Panggungjati Kecamatan Taktakan Kota Serang merupakan salah satu daerah peternak ayam kampong. Peternak di Desa Panggungjati melakukan ternak ayam kampong pada tahap pembibitan dan penggemukan, namun bibit yang mereka milliki jumlahnya terbatas sehingga belum mampu memenuhi permintaan pasar. Hal ini disebabkan karena peternak mengalami kesulitan dalam memperoleh bibit dengan mudah, cepat dan berkualitas, sehingga bibit harus dicari dari tempat yang berbeda-beda dari kampung ke kampung yang menyebabkan kualitas ayamnya pun tidak sama. Hal ini menghambat proses produksi ternak ayam kampong yang berkelanjutan.

Apabila peternak memiliki bibit yang cukup, maka proses produksi mulai dari pembibitan dan penggemukan dapat berjalan dengan baik. Selain itu peternak tidak hanya fokus pada pembibitan dan penggemukan tetapi juga dapat melakukan diversifikasi usaha yaitu dengan cara menjual bibit yang telah ditetaskan atau dikenal dengan DOC (Day Old Chick).

Selain itu, untuk memenuhi keinginan konsumen yang memilliki karakteristik yang beragam dalam memanfaatkan dan mengolah ayam kampong, khususnya daerah perkotaan yaitu kepraktisan untuk mengolahnya, ayam kampung dijual tidak hanya dalam bentuk ayam hidup tetapi juga dalam bentuk yang sudah dipotong, dibersihkan dan dikemas, bahkan ada yang sudah diolah setengah matang. Kondisi tersebut mengharuskan ayam harus segera dapat terjual karena sifatnya yang relatif tidak tahan lama. Karena sifatnya yang tidak tahan lama, maka ayam yang telah di kemas tersebut diproduksi dalam jumlah terbatas. Oleh karena itu peternak membutuhkan manajemen usaha pemasaran yang modern. Manajemen pemasaran yang dijalankan saat ini adalah penjualan secara tradisional, sehingga pemasarannya tidak luas dan pendapatan yang diperoleh tidak maksimal

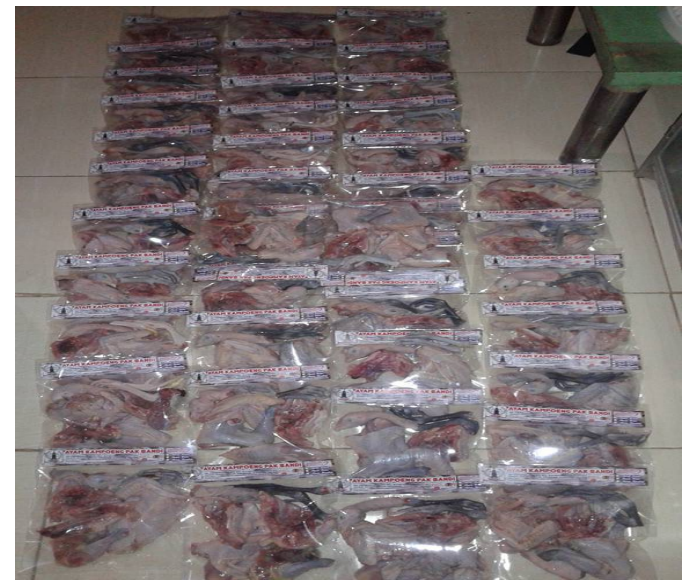

Gambar 2

Ayam kampong potong dan kemas

\section{Permasalahan Mitra}

Pemasaran dalam dunia peternakan cukup berperan dalam peningkatan hasil pendapatan peternak dan sekaligus dapat meningkatkan tingkat perekonomian bangsa Indonesia. Pemasaran merupakan proses dari alur produksi ternak agar sampai ke tangan konsumen. Berdasarkan hasil diskusi dengan peternak di Desa Panggungjati Kecamatan Taktakan, terdapat beberapa permasalahan pemasaran hasil peternakan, antara lain:

1. Bibit ayam kampong harus dicari dari tempat yang berbeda-beda secara manual dari satu kampung ke kampung lainnya, maka diperlukan suatu akses untuk mendapatkan informasi kemana peternak ayam kampong dapat memperoleh bibit ayam kampong dengan mudah, cepat, dan memiliki kualitas yang baik. 
2. Karakteristik konsumen yang beragam menyebabkan diperlukannya suatu teknik pemasaran yang terbaik untuk mengikat konsumen dan memenuhi selera konsumen.

3. Belum dimanfaatkannya teknologi informasi sebagai alat untuk pemasaran ayam kampong di Desa Panggungjati. Hal ini disebabkan karena masih rendahnya pemahaman peternak tentang teknologi informasi dalam hal ini adalah "internet".

Berdasarkan diskusi dan kesepakatan bersama, permasalahan mengenai perolehan bibit dan pemasaran ayam kampong adalah:

1. Belum dimanfaatkannya teknologi informasi sebagai alat untuk mencari informasi mendapatkan bibit yang mudah dan cepat serta pemasaran ayam kampong di Desa Panggungjati.

2. Masih rendahnya pemahaman peternak tentang teknologi informasi dalam hal ini adalah penggunaan internet yang dapat digunakan untuk memasarkan ayam kampong.

Melalui kegiatan program kemitraan masyarakat ini, diharapkan dapat mengatasi permasalahan peternakan di Desa Panggungjati Kecamatan Taktakan Kota Serang.

\section{METODE PELAKSANAAN}

Di bidang peternakan, membudidayakan ternak untuk mendapatkan hasil banyak dan berkualitas merupakan hal yang penting, selain itu penting juga agar hasil yang diperoleh dapat terjual di pasaran dengan harga yang bagus, banyak, dan terjual semua. Pada pengabdian masyarakat ini berusaha membantu peternak dalam memperoleh bibit dengan cepat, mudah dan berkualitas serta memasarkan hasilnya dengan menggunakan teknologi informasi yaitu memanfaatkan internet. Penggunaan media internet merupakan sesuatu cara dalam rangka memperoleh informasi secara global yang dapat digunakan oleh peternakan dalam kegiatan peternakan. Dalam kegiatan ini memberikan wawasan dan menyediakan teknologi informasi internet kepada kelompok peternak. Pada kegiatan ini kelompok peternak akan diperkenalkan untuk menggunakan teknologi informasi berupa internet untuk menambah wawasan peternak akan pentingnya informasi dalam rangka meningkatkan hasil dan pendapatan peternakan.

\section{Identifikasi Pengetahuan}

Pada tahap ini adalah melakukan identifikasi pengetahuan peternak dalam pemanfaatan internet sebagai alat untuk memperoleh informasi tentang perolehan bibit dan pemasaran ayam kampong.

2. Melakukan diskusi dengan peternak untuk membantu peternak dalam menerapkan teknologi informasi internet yang akan membantu mendapatkan informasi mulai dari proses budidaya sampai kepada proses pemasaran. Menetapkan kesediaan peternak untuk belajar internet.

\section{Pelatihan Belajar Internet}

Pada tahap ini peternak yang bersedia untuk berlatih internet dan membuat blog/medsos tentang hasil masingmasing peternak.

\section{Penerapan internet masuk desa.}

Pada tahap ini diharapkan peternak bersedia untuk melakukan proses edukasi dan pelaksanaan internet.

\section{Evaluasi dan Monitoring}

Pada tahap akhir ini Tim pelaksana mengukur keberhasilan peternak dalam mendapatkan teknologi informasi internet serta dianalisis hambatan untuk keberlanjutan kegiatan tersebut.

\section{HASIL DAN PEMBAHASAN}

\section{Identifikasi Pengetahuan}

Pada tahap ini dilakukan identifikasi pengetahuan peternak dalam pemanfaatan internet sebagai alat untuk memperoleh informasi tentang perolehan bibit dan pemasaran ayam kampong. Berdasarkan hasil diskusi dengan peternak ayam kampong, peternak ayam kampong masih ada yang memiliki pemahaman yang rendah akan pemanfaatan teknologi informasi.

Tabel 1

Penjualan melalui Internet

\begin{tabular}{lcc}
\hline \multicolumn{1}{c}{ Keterangan } & Jumlah & $\%$ \\
\hline $\begin{array}{l}\text { Pengetahuan peternak tentang penjualan } \\
\text { melalui internet }\end{array}$ & & \\
Tidak Pernah & 0 & 0 \\
$\quad$ Pernah & 2 & 100 \\
Kemampuan Menggunakan Internet & 1 & 50 \\
$\quad$ Bisa & 1 & 50 \\
Tidak Bisa & & \\
Teman yang menjual hasil dengan internet & 1 & 50 \\
Ada & 1 & 50 \\
Tidak Ada & & \\
\end{tabular}

\section{Melakukan diskusi dengan peternak}

Diskusi dengan peternak dilakukan untuk membantu peternak dalam menerapkan teknologi informasi internet yang akan membantu mendapatkan 
informasi mulai dari proses budidaya sampai kepada proses pemasaran. Pada tahap ini juga menetapkan kesediaan peternak untuk belajar internet.

\section{Pelatihan Belajar Internet}

Pada tahap ini peternak berlatih internet dan membuat blog/medsos tentang hasil masing-masing peternak.

\section{Penerapan internet masuk desa}

Pada tahap ini diharapkan masing-masing peternak bersedia untuk melakukan proses edukasi dan pelaksanaan internet.

\section{Evaluasi dan Monitoring}

Pada tahap ini tim pelaksana mengukur keberhasilan peternak dalam menerapkan teknologi informasi internet untuk keberlanjutan usaha mereka. Berdasarkan hasil diskusi dengan para peternak, para peternak antusias melakukan penjualan dan aktivitas lainnya dengan menggunakan penerapan internet karena:

1. Para peternak dapat meningkatkan produktivitas dan reproduktivitas ayam kampong. Selain itu internet dapat dijadikan sarana berkomunikasi dengan peternak lain ataupun stakeholder yang berada jauh untuk mencari bibit dengan mudah dan cepat. Apabila peternak memiliki bibit yang cukup, maka proses produksi mulai dari pembibitan dan penggemukan dapat berjalan dengan baik. Selain itu peternak juga tidak hanya fokus pada pembibitan dan penggemukan tetapi juga dapat melakukan diversifikasi usaha yaitu dengan cara menjual bibit yang telah ditetaskan atau dikenal dengan DOC (Day Old Chick). Aktivitas ini diharapkan mampu meningkatkan pendapatan para peternak.

2. Para peternak dapat berkomunikasi dengan konsumen, produsen, dan peternak lain ataupun stakeholder yang berada jauh untuk melakukan fungsi pemasaran. Para peternak dapat memasarkan ayam kampong dengan mudah dan cepat. Dikarenakan Ayam kampong yang dijual tidak hanya dalam bentuk ayam hidup tetapi juga dalam bentuk yang sudah dipotong, dibersihkan dan dikemas, bahkan ada yang sudah diolah setengah matang sehingga ayam harus segera dapat terjual karena sifatnya yang relatif tidak tahan lama, maka peternak membutuhkan manajemen usaha pemasaran yang modern salah satunya penjualan secara online dan/atau menggunakan media sosial untuk memasarkannya, sehingga pemasarannya menjadi luas dan pendapatan yang diperoleh maksimal.

\section{KESIMPULAN DAN SARAN}

\section{Kesimpulan}

Pengabdian masyarakat dilakukan untuk memberikan metode mencari informasi mendapatkan bibit dengan mudah, cepat dan berkualitas serta meningkatkan pemasaran ayam kampong dengan memanfaatkan teknologi informasi dengan internet. Hasil yang ingin dicapai adalah peternak dapat melakukan proses produksi yang berkelanjutan dan memiliki manajemen pemasaran yang baik sehingga dapat meningkatkan pendapatan

\section{DAFTAR REFERENSI}

\section{http://dispertan.bantenprov.go.id/}

\section{https://kominfo.go.id/}

Kadir, A. 2003. Pengenalan sistem informasi. Yogyakarta: Andi

Kotler, Philip and Gary Armstrong. 2012. Prinsipprinsip Pemasaran. Edisi 13. Jilid 1. Jakarta, Erlangga.

Luciana, S.A. 2013. Penerapan E-commerce Sebagai Upaya Meningkatkan Persaingan Bisnis Perusahaan. STIE Perbanas Surabaya. Surabaya

Nugroho, A. 2006. E-commerce memahami perdagangan modern di dunia maya. Bandung: informatika

Purba, O.W., dan Wahyudi, A. A. 2001. Mengenal e-commerce. Jakarta: elex media

Prasetio, adhi. 2010. Cara Mudah Membuat Desain Web Untuk Pemula. Mediakita

Sarwono, J., danPrihartono, A. H. 2010. Perdagangan online: cara bisnis di internet. Jakarta: elex media

Supradono, B. 2014. Strategi Pemasaran Lewat Internet (cybermarketing). http://jurnal.unimus.ac.id Sutejo, S.B. 2006. Internet Marketing: Konsep Dan Persoalan Baru Dunia Pemasaran. Jurnal Manajemen Vol 6. No.1

Sutrisno, J. 2011. Strategi Pengembangan Teknologi E-commerce dengan Metode Swot: Studi Kasus: PT. Chingmix Berhan Sejahtera. Jurnal Telematika MKOM, Vol.3 No. 2 